\title{
PRELIMINARY DATA ON POLYCHLORINATED BIPHENYLS (PCBS) IN COWS’ MILK FROM BOSNIA AND HERZEGOVINA MARKET
}

\author{
Jasmina J. Djedjibegovic ${ }^{1}$, Amila A. Turalic ${ }^{1}$, Naida N. Ajdinovic ${ }^{1}$, Aleksandra A. Marjanovic ${ }^{1}$, Elma E. \\ Omeragic $^{* 1}$, Amir A. Causevic ${ }^{2}$, Faruk F. Caklovica ${ }^{3}$, Miroslav M. Sober ${ }^{1}$ \\ ${ }^{1}$ University of Sarajevo, Faculty of Pharmacy, 71000 Sarajevo, Zmaja od Bosne 8, \\ Bosnia and Herzegovina \\ ${ }^{2}$ Institute for Public Health FBiH, 71000 Sarajevo, Marsala Tita 9, Bosnia and Herzegovina \\ ${ }^{3}$ University of Sarajevo, Veterinary Faculty, 71000 Sarajevo Zmaja od Bosne 90, \\ Bosnia and Herzegovina
}

\author{
${ }^{*}$ Corresponding author: \\ Phone: +38733586178 \\ Fax: +38733586178 \\ E-mail: elma.omeragic@ffsa.unsa.ba
}

\begin{abstract}
In this work, both farm milk samples $(n=3)$, as well as samples of milk from Bosnia and Herzegovina market $(n=7)$, were analyzed to quantify the presence of polychlorinated biphenyls. The PCB content (as Aroclor 1254) was determined in the fat extracts using the PCB ELISA kit, according to the procedure provided by the manufacturer.

The total PCB concentrations (as Aroclor 1254) in individual milk sample ranged from <LoD to 787.74 $\mu \mathrm{g} / \mathrm{kg}$ lipid weight (I.w.). The calculated $\Sigma_{6} \mathrm{PCB}$ were ranged from <LoD to $187.72 \mu \mathrm{g} / \mathrm{kg}$ I.w.

In one out of ten analyzed samples the presence of PCB higher than maximum limit (ML) was found. However, the absorbance measured for this sample is out of the linear range. In this case the sample can be considered as a suspect and should be analyzed with the quantitative confirmatory method. In other milk samples the concentration of PCB was in the acceptable range, and far below the ML.
\end{abstract}

Key words: polychlorinated byphenils, Aroclor1254, ELISA, milk

\section{INTRODUCTION}

Consumption of cow's milk has long tradition in human nutrition (Haug, 2007). Milk is a very important source of dietary energy, protein and fat. Cow milk contains high-quality proteins, with good balance of all the essential amino acids (FAO, 2013). Proteins have multiple roles in the body (e.g. to form antibodies, to build and repair body tissues etc.). Cow's milk also contains calcium, phosphorus, magnesium, and potassium and it is a significant source of vitamins B, A and D. The U.S. government's Dietary Guidelines suggest the following daily consumption of milk: for children 1-8 years old, 2 servings (one serving is $125 \mathrm{ml}$ ), children older than 9 years and adults 3 servings (IDFA, 2014).
Polychlorinated biphenyls (PCBs) make up a highly toxic group of pollutants that are known to persist in the environment, accumulate in lipids, tend to biomagnify through the food chain, and have the potential to cause adverse health effects (Djedibegović, 2015). Currently, the major sources of PCBs are their environmental deposites from past releases; hence, volatilization from land and surface water is an important source for the global distribution of PCBs (ATSDR, 2000). Generally, fatty foods of animal origin are the major sources of human exposure to lipophilic contaminants (Ahmadkhaniha, 2017). Previous studies have shown that the main route of human exposure to PCB is contaminated 
food. Milk is one of the main constituent of the daily diet. Bosnia and Herzegovina $(\mathrm{BiH})$ is, according to the GEMS World Health Organization (FAO/WHO, 2012), the cluster with the highest uptake of milk per capita (456.5 g/day). Thus, knowledge of cow's milk contamination by PCBs provides important information about human exposure to these contaminants, through the ingestion of dairy products.

\section{MATERIALS AND METHODS}

\section{Chemicals and reagents}

Cyclohexane, methanol and 2-propanol (all analytical grade), decane (purum), namyl alcohol (sp. gr. 0.185) and tetrabutylammonium sulphate (p.a.) were purchased from Sigma-Aldrich (Seelze, Germany).

Sodium sulphite (p.a.) was purchased from Kemika (Zagreb, Croatia). Sulphuric acid $(98 \%$, p.a) was purchased from Merck (Darmstadt, Germany). PCB standard (Aroclor 1254) was purchased from Dr Ehrenstorfer GmbH (Augsburg, Germany).

Nitrogen 5.0 was supplied from Messer (Sarajevo, BiH). Ultrapure water $(>18 \mathrm{~m} \Omega$ ) was supplied by Arium ${ }^{\circledR}$ mini Lab Water System (Goettingen Germany). PCB standard (PCB30) was purchased from $\mathrm{Dr}$ Ehrenstorfer GmbH (Augsburg, Germany).

\section{Sample collection and treatment}

Cow's milk samples from three different farms in Bosnia and Herzegovina were collected in May 2014 and commercial packed pasteurised milk was purchased in Sarajevo (Bosnia and Herzegovina) (7 samples). Samples from farms $(50 \mathrm{ml})$ and from market $(0,5 \mathrm{~L})$ were transported to the laboratory, labelled (F1-F3 samples from farms and T1-T7 samples from market) and stored at $-20^{\circ} \mathrm{C}$ until analysis.

From each collected sample, an aliquot of $11 \mathrm{~mL}$ were treated with sulfuric acid (10 $\mathrm{mL}$ ) and amyl alcohol (1 $\mathrm{mL})$, carefully mixed and centrifuged at $1200 \mathrm{rpm}$ for 5 minutes (IEC CL-10 Centrifuge, Thermo Fisher Scientific Inc., USA). The upper layers were transferred into clean test tubes, dried $\left(36{ }^{\circ} \mathrm{C}\right)$ in a stream of nitrogen and the fat fraction of milk was weighted.
To each of the measured aliquot of fat 2 $\mathrm{mL}$ of cyclohexane and $50 \mu \mathrm{L}$ of the internal standard (PCB30) were added and mixed on a vortex (Vortex-Genie 2, Scientific Industries, NY, USA).

The obtained mixture was cleaned with a concentrated sulfuric acid as described for fish and shellfish fat (Omeragic et al, 2016; Djedjibegovic at al 2015). Purified mixture was evaporated using nitrogen and dissolved in aqueous methanol $(1: 1 \mathrm{v} / \mathrm{v})$.

\section{Determination of PCBs}

The PCB content (as Aroclor 1254) was determined in the fat extracts using the PCB ELISA kit (Abraxis/Biosense PCBs ELISA kit, Warminster, PA, USA), according to the procedure provided by the manufacturer. The spectrophotometric quantification was performed at $450 \mathrm{~nm}$ using RPA-I RaPID Analyzer (spectro-photometer, Strategic Diagnostics Inc, Ne-wark, DE USA). The calibration curve was constructed with Aroclor 1254 standard solutions $(0.25,1.5,2.5,5.0,10.0$ and 25.0 $\mathrm{ng} / \mathrm{mL}$ ). The results were calculated as the mean of three measurements, using logit transformation (equation 1) (Bolton, 1997).

$\operatorname{logit} A / A_{0}=\log \left(\frac{\frac{A}{A_{0}}}{1-\frac{A}{A_{0}}}\right)$

where $A$ is mean absorbance value for standard/sample and $A_{\circ}$ is a mean absorbance value for negative control.

\section{Calculation}

For the method limits of detection (LoD) and limits of quantification (LoQ), a conservative estimate of SD was taken from the standard deviation of measurements of a concentration T6 sample. The method limits of detection and limits of quantification were calculated using equations 2 and 3 , respectively.

$$
\begin{aligned}
& L o D=3 * S D \\
& L o Q=10 * S D
\end{aligned}
$$

The resolution of the ELISA test (AC) was calculated using equation 4 :

$A C=2 \times \sqrt{2 \times S D}$ 
where SD is the standard deviation at the concentration of interest (Richter, 1994).

As a concentration of interest, concentration corresponding to 95 percent of the distribution of $\Sigma_{6} \mathrm{PCB}$ concentrations found in milk samples in European countries (EFSA, 2012) was defined, and it was 16 $\mu \mathrm{g} / \mathrm{kg}$ of fat. The SD of the measurements at the PCB level detected in T1 sample and calculated as $\Sigma_{6} \mathrm{PCB}$ concentrations $(12.22 \mu \mathrm{g} / \mathrm{kg}$ on a lipid basis (I.w.)) was used as the concentration of interest.

Recovery factor was estimated by analysing positive control using equation 5 :

$R_{s}=\frac{C_{s}}{C_{k}} * 100$

where $C_{s}$ is the measured concentration and $C_{k}$ expected concentration of positive control $(5 \mathrm{ng} / \mathrm{mL})$.

The positive and negative control were provided in the commercial PCB ELISA kit. Positive control contained $5 \mathrm{ng} / \mathrm{mL}$ of $\mathrm{PCB}$ (as Aroclor 1254) in methanol solution containing preservative and stabilizers and negative control was a methanol solution containing preservative and stabilizers without any detectable PCB.

Concentrations of PCBs (as Aroclor 1254) are presented as $\mu \mathrm{g} / \mathrm{L}$ ( $\mu \mathrm{g} / \mathrm{L}$ w.w.) of native sample and $\mu \mathrm{g} / \mathrm{kg}$ on a lipid basis $(\mu \mathrm{g} / \mathrm{kg}$ I.w.).

\section{RESULTS AND DISCUSSION}

Linearity of the ELISA test for PCBs determination in milk samples was in the range of $0.25-25.0 \mathrm{ng} / \mathrm{mL}\left(R^{2}=0.9804\right)$ (Figure 1). The limit of detection (LoD) was 0.19 $\mu \mathrm{g} / \mathrm{L}$ w.w. and the limit of quantification (LoQ) was $0.63 \mu \mathrm{g} / \mathrm{L}$ w.w.

The recovery for the positive control was $96.2 \%$. The resolution of the ELISA test was $0.13 \mu \mathrm{g} / \mathrm{l}$ w.w. $(8.50 \mu \mathrm{g} / \mathrm{kg}$ I.w.) at 0.33 $\mu \mathrm{g} / \mathrm{l}$ w.w. $(12.21 \mu \mathrm{g} / \mathrm{kg}$ l.w.)

The presence of PCBs was not detected in the blank indicating the absence of subsequent contamination of samples during preparation.

The requirement for analytical method performances in food safety control is LoQ less than one-fifth of the maximum level $(\mathrm{ML})$ for the PCB concentration (EFSA,
2012). The ML of $\Sigma_{6}$ PCBs in milk is 40 $\mu \mathrm{g} / \mathrm{kg}$ I.w. (EC, 2011), and the LoQ analytical methods should be less than 8 $\mu \mathrm{g} / \mathrm{kg}$ I.w., which was achieved by the ELISA test in our work. The ELISA test performances obtained in our work were acceptable in terms of accuracy.

The test resolution shows that we were able to statistically discriminate concentration of interest (16 $\mu \mathrm{g} / \mathrm{kg}$ l.w.) from permitted maximum level set by European Commission (EFSA, 2012) and this test is acceptable for screening purposes.

PCBs can be analyzed and quantified as Aroclor mixtures or as individual congeners. Permitted maximum levels of the PCBs in food are set as sum of specific number of congeners.

PCB data in this paper are presented as equivalents of Aroclor 1254. These data cannot be directly compared to permitted maximum levels set by European Commission.

Since each Aroclor mixture has known PCB congener composition, we multiplied our results by sum of weight percents of six indicator congeners $(0.19,5.38,8.02$, $5.80,3.71,0.67$ for PCB 28, 52, 101, 138, 153 and 180, respectively) in Aroclor 1254 mixture (Frame, 1996).

The PCB concentrations in milk samples are summarised in Table 1. The total PCB concentrations (as Aroclor 1254) in individual milk sample ranged from $\angle$ LoD to $787.74 \mu \mathrm{g} / \mathrm{kg}$ I.w.. The calculated $\Sigma_{6} \mathrm{PCB}$ were ranged from $<$ LoD to $187.72 \mu \mathrm{g} / \mathrm{kg}$ I.w.

With the exception of sample T6, PCBs concentrations found in all other samples were greater than LoQ. The PCBs content in milk fat varied for factor 4 . In sample F1 the PCBs concentration was at least one order of magnitude greater than that found in other samples (Table 1). At the same time, this is the only sample in which the concentration of PCB was greater than ML (40 $\mu \mathrm{g} / \mathrm{kg} \mathrm{I.w.),} \mathrm{while} \mathrm{concentrations} \mathrm{in}$ other samples were at least three times lower than ML. In the inspection of the results it was noted that the measured absorbance of $F 1$ sample was significantly outside the linear range, and this sample could be described as suspect. 


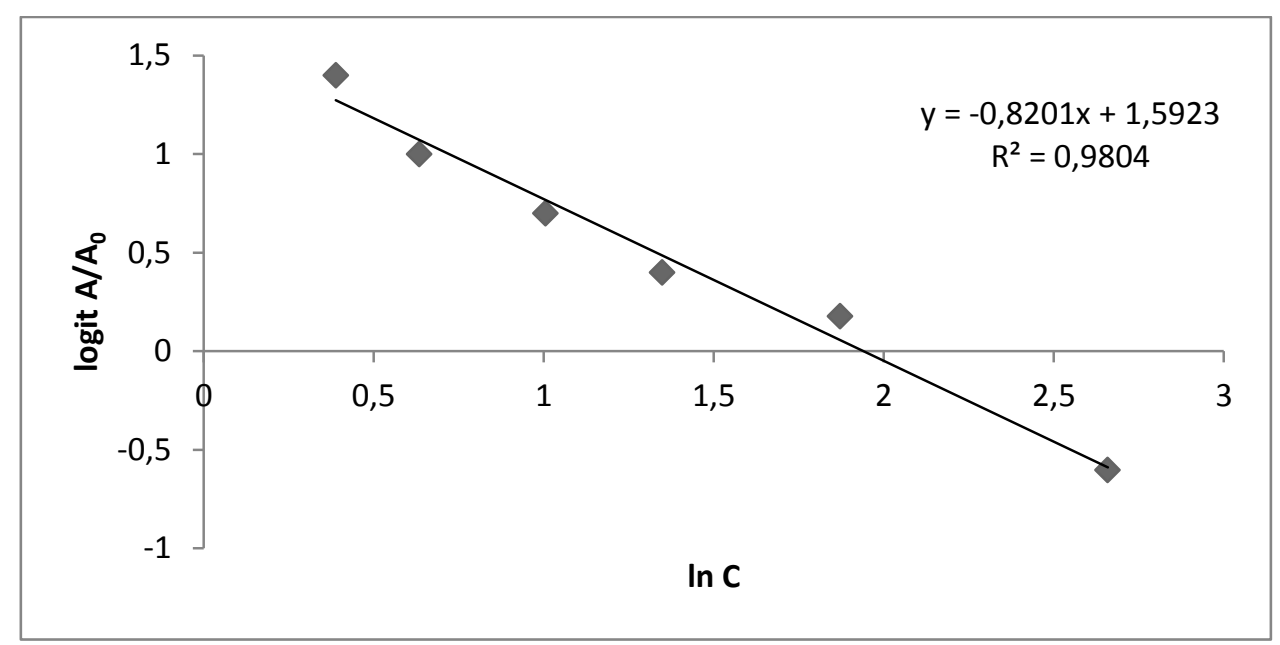

Figure 1. The standard calibration curve based on Aroclor 1254

Table 1.

The PCB concentrations in milk samples

\begin{tabular}{|c|c|c|c|c|c|}
\hline \multirow{2}{*}{$\begin{array}{l}\text { Sample } \\
\text { ID }\end{array}$} & \multicolumn{3}{|c|}{ Aroclor1254 } & \multicolumn{2}{|l|}{$\Sigma_{6} \mathrm{PCB}$} \\
\hline & $\operatorname{PCB}_{\text {ELISA }}(\mu \mathrm{g} / \mathrm{L})$ & $\mathrm{PCB}_{\text {w.w. }}(\mu \mathrm{g} / \mathrm{L})$ & $\mathrm{PCB}_{\text {I.w. }}(\mu \mathrm{g} / \mathrm{kg})$ & $\mathrm{PCB}_{\text {w.w. }}(\mu \mathrm{g} / \mathrm{L})$ & $\mathrm{PCB}_{\mathrm{I} . \mathrm{w}} \cdot(\mu \mathrm{g} / \mathrm{kg})$ \\
\hline $\begin{array}{l}\text { Positive } \\
\text { control }\end{array}$ & $4.81^{* *}$ & - & - & - & - \\
\hline $\mathrm{T} 1$ & 15.27 & 1.39 & 51.22 & 0.33 & 12.21 \\
\hline T2 & 11.48 & 1.04 & 33.77 & 0.25 & 8.05 \\
\hline T3 & 11.48 & 1.04 & 42.60 & 0.25 & 10.15 \\
\hline T4 & 10.23 & 0.93 & 30.99 & 0.22 & 7.38 \\
\hline T5 & 15.89 & 1.44 & 47.52 & 0.34 & 11.32 \\
\hline T6 & 3.30 & 0.30 & 13.46 & 0.07 & 3.21 \\
\hline $\mathrm{T} 7$ & ND & ND & ND & ND & ND \\
\hline $\mathrm{F} 1$ & 209.70 & 19.06 & 787.74 & 4.54 & 187.72 \\
\hline F2 & 8.60 & 0.78 & 50.46 & 0.19 & 12.02 \\
\hline F3 & 7.53 & 0.68 & 45.62 & 0.16 & 10.87 \\
\hline Blank & ND & ND & ND & ND & ND \\
\hline
\end{tabular}

T-milk samples from market; $F$ - milk samples from farms;

"Recovery for the positive control is $96.2 \%$; ND - not detected, i.e. $<$ LoD

According to the EFSA Report (EFSA, 2010 ), the mean of $\Sigma_{6} P C B$ in 5640 collected milk products in 18 European countries, Iceland and Norway, was $9.2 \pm 3.4 \mu \mathrm{g} / \mathrm{kg}$ l. w. (median $9.0 \mu \mathrm{g} / \mathrm{kg}$ I.w.).

The average concentration of $\Sigma_{6} \mathrm{PCB}$ in milk samples analyzed in this paper was $26.29 \pm 56.86 \mu \mathrm{g} / \mathrm{kg}$ I.w., with evident influence of extreme $\mathrm{F} 1$ sample (median $10.51 \mu \mathrm{g} / \mathrm{kg}$ I.w.). By omitting the F1 sample, the average content of $\Sigma_{6} \mathrm{PCB}$ in our samples was $8.36 \pm 4.24 \mu \mathrm{g} / \mathrm{kg}$ I.w. (median $10.15 \mu \mathrm{g} / \mathrm{kg}$ l.w.).

In conclusion, levels of $\Sigma_{6} \mathrm{PCB}$ in our samples generally do not deviate from the European samples.
The F1 sample contains a significantly higher level of $\Sigma_{6} \mathrm{PCB}$. The cause of high level of PCB in this sample could be a result of residue accumulation in the tissues following the cattle's exposure from feeding on contaminated feedstocks or from drinking contaminated water (Gomes Martins, et al., 2013).

Bernard et al. (2002) found a concentration of six indicator PCBs up to 160 $\mu \mathrm{g} / \mathrm{kg} \mathrm{I.w.} \mathrm{in} \mathrm{milk} \mathrm{originally} \mathrm{from} \mathrm{cows} \mathrm{fed}$ with contaminated food. Turrio-Baldassarri et al. (2009) found PCBs residues in concentrations ranging from $183-477 \mu \mathrm{g} / \mathrm{kg} \mathrm{I}$. w. in milk samples originally from farm located near the factory for PCB production. $\mathrm{PCB}$ mixtures were never manu- 
factured in $\mathrm{BiH}$, nor was there any production of equipment containing PCBs, but during the last civil war in $\mathrm{BiH}$, large amounts of persistent organic pollutants were generated and emitted into the environment as a result of partial or complete destruction of industrial facilities, military targets, infrastructure, explosions and uncontrolled fires (Klánová et al. 2007).

Effects of non-dioxin-like PCBs (ndl-PCBs) on human health are still not sufficiently explored to make it possible to assess the risks to human health. Therefore, the risk is further estimated based on the sum of dioxin-like PCBs (dl-PCBs), polychlorinated dibenzo-p-dioxins (PCDDs) and polychlorinated dibenzofurans (PCDFs), expressed as pg toxic equivalent (TEQ) in $g$ fat.

This concentration can be calculated with sufficient accuracy only if the concentrations of each PCB congener, PCDD and PCDF are known. Unlike six indicator PCBs, dl-PCBs, PCDDs, and PCDFs show some variation in content in individual PCBs mixture, so TEQ content in individual Ar1254 series varied for one order of magnitude (17-392 pg TEQ/g Ar11254) (EFSA, 2005). Considering significant uncertainty, this calculation was not used in the paper. However, in the EFSA report, correlation of content of $\Sigma_{6}$ PCB in analyzed milk samples $(n=213)$ and total TEQ ${ }_{\text {WHO05 }}$ was described by regression equation: ndl-PCB $=10.91 \mathrm{dl}-$ $\mathrm{PCB}+1.88$ (EFSA, 2012). Using this equation the calculated TEQ samples would be $0.00-0.95 \mathrm{pg} / \mathrm{g}$ fat (except for sample F1: $17.03 \mathrm{pg} / \mathrm{g}$ of fat), which is significantly below ML of $5.5 \mathrm{pg}$ $T E Q_{W H O 05} / g$ of fat $(E C, 2011)$.

\section{CONCLUSIONS}

The analytical performance of the commercial ELISA kit allows its application as a screening method for determining PCBs in milk.

The presence of PCBs was detected in 9/10 of analyzed milk samples. One out of ten samples was suspected to contain high levels of PCBs. This sample originated from a farm and it is possible to reflect the elevated contamination of forage, which should be further examined. Generally, this preliminary study suggested that PCB concentrations found in milk samples from the $\mathrm{BiH}$ market, do not indicate an unacceptable health risk to consumers.

\section{REFERENCES}

1. Ahmadkhaniha, R., Nabizadeh Nodehi, R., Mohammadi Aghamirloo, H. (2017). Polychlo-rinated biphenyls (PCBs) residues in commercial pasteurized cows' milk in Tehran, Iran. Journal of Environmental Health Science and Engineering, 15, 15.

2. ATSDR (2000). Public health statement polychlorinated biphenyls (PCBs). (Retrieved Dec. 20, 2018 from

https://www.atsdr.cdc.gov/ToxProfiles/tp17-c1b.pdf).

3. Bernard A., Broeckaert F., De poorter G., De Cock A., Hermans C., Saegerman C., Houins G. (2002). The Belgian PCB/Dioxin inci-dent: analysis of food chain contamination and health risk evaluation. Environmental Research: Section A, 88, 1-18.

4. Bolton, S. (1997). Pharmaceutical Statistics: Practical and Clinical Application, $3^{\text {rd }}$ Ed., Marcel Decker Inc., New York.

5. Djedjibegovic, J., Marjanovic, A., Burnic, S., Omeragic, E., Dobraca, A., Sober, M. (2015). Polychlorinated biphenyls (PCBs) in fish from the Sana River (Bosnia and Herzegovina): A preliminary study on the health risk in sport fishermen. Journal of Environmental Science and Health, Part B 50, 638-644.

6. EC (2011). Commission regulation 1259/2011 of December 2011 amending Regulation (EC) No $1881 / 2006$ as regards maximum levels for dioxins, dioxin-like PCBs and non dioxin-like PCBs in foodstuffs. European Commission. Official Journal of the European Union, $L$ 320/18.

7. EFSA (2005). Opinion of the scientific panel on contaminants in the food chain on a request from the commission related to the presence of non dioxin-like polychlorinated biphenyls (PCBs) in feed and food. European Food Safety Authority (EFSA). EFSA Journal, 284, 1-137.

8. EFSA (2010). Scientific report, results of the monitoring of non dioxin-like PCBs in food and feed. European Food Safety Authority (EFSA). EFSA Journal, 8, 1701-1736.

9. EFSA (2012). Scientific Report of EFSA: Update of the monitoring of levels of dioxins and PCBs in food and feed. European Food Safety Authority (EFSA). EFSA Journal, 10 (7), 2832.

10. FAO (2013). Milk and dairy products in human nutrition. (Retrieved Sept. 25, 2018 from http://www.fao.org/docrep/018/i3396e/i3396e.p df).

11. Frame, G.M., Cochrane, J.W., Bowadt, S.S. (1996). Complete PCB congener distributions for 17 Aroclor mixtures determined by 3 HRGC 
systems optimized for comprehensive, quantitative, congener specific analysis. Journal of High Resolution Chromatography, 19, 657-668.

12. Gomes Martins, J., Amaya Chávez, A., Waliszewski, M. S., Colín Cruz, A., García Fabila M. M. (2013). Extraction and clean-up methods for organochlorine pesticides determination in milk. Chemosphere, 92, 233-246.

13. Haug, A., Høstmark, T.A., Harstad, M.O. (2007). Bovine milk in human nutrition - a review. Lipids in Health and Disease, 6, 1-16.

14. IDFA (2014). International Dairy Foods Associations. Importance of milk in diet. (Retrieved Sept. 25, 2018 from https://www.idfa.org/news-views/mediakits/milk/importance-of-milk-in-diet).

15. Klánová, J., Jiří K., Kostrhounová R., Holoubek I. (2007). Are the residents of former Yugoslavia still exposed to elevated PCB levels due to the Balkan wars?: Part 1: Air sampling in
Croatia, Serbia, Bosnia and Herzegovina. Environment International, 33, 719-726.

16. Omeragic, E.E., Marjanovic, A.A, Djedjibegovic, J.J, Dobraca, A.A., Sober, M.M. (2016). The content of polychlorinated biphenyls and organochlorine pesticides in tissues of date mussel (Lithophaga lithophaga L., 1758) from the Sarajevo fish market. Food and Feed $\mathrm{Re}$ search, 43, 9-18.

17. Richter, C.A.,Drake, J.B., Giesy, J.P. (1994). Immunoassay monitoring of polychlorinated biphenyls (PCBs) in the Great Lakes. Environmental Science and Pollution Research, 1, 69-74.

18. Turrio-Baldassarri L., Alivernini, S., Carasi, S., Casella, M., Fuselli, S., lacovella, N., lamiceli, A.L., La Rocca, C., Scarcella., C., Battistelli, C. L. (2009), PCB, PCDD and PCDF contamination of food of animal origin as the effect of soil pollution and cause of human exposure in Brescia. Chemosphere, 76, 278-285.

\section{САДРЖАЈ ПОЛИХЛОРОВАНИХ БИФЕНИЛА У МЛЕКУ СА БИХ ТРЖИШТА}

Јасмина Ј. Ђеђибеговић ${ }^{1}$, Амила А. Туралић ${ }^{1}$, Наида Н. Ајдиновић ${ }^{1}$, Александра А Марјановић ${ }^{1}$ Елма Е. Омерагић*1, Амир А. Чаушевић ${ }^{2}$, Фарук Ф. Чакловица ${ }^{3}$, Мирослав М. Шобер ${ }^{1}$

${ }^{1}$ Универзитет у Сарајеву, Фармацеутски факултет, 71000 Сарајево, Змаја од Босне 8, Босна и Херцеговина

2 Завод за јавно здравство ФБиХ, Маршала Тита 9, Босна и Херцеговина

${ }^{3}$ Универзитет у Сарајеву, Ветеринарски факултет, 71000 Сарајево, Змаја од Босне 90, Босна и Херцеговина

Сажетак: У овом раду су анализирани узорци млека са фрарми (H=3), те узорци из комерцијалних извора (H=7) у Босни и Херцеговини (БиХ) на присуство полихлорованих бифенила (ПХБ). Садржај ПХБ (као Арохлор 1254) је одређен у екстракту масти кориштењем ПХБ ЕЛИСА кит, према процедури предложеној од стране произвођача.

Садржај укупних ПХБ (изражен као Арохлор 1254) у појединим узорцима млека се кретао у распону <LoD to $787.74 \mu \mathrm{g} / \mathrm{kg}$ I.w. Израчунати садржај $\Sigma_{6} П Х Б$ био је у распону <LoD to 187.72 $\mu \mathrm{g} / \mathrm{kg}$ I.w. У једном од десет анализираних узорака нађена концентрација ПХБ је била већа од максимално дозвољене концентрације (МДК), међутим, измерена апсорбанца за овај узорак налази се изван линеарног распона, тако да се овај узорак може сматрати суспектним, што би требало проверити референтном квантитативном методом.

У осталим узорцима млека, концентрације ПХБ су биле у прихватљивим границама, и далеко од максимално дозвољене концентрације.

Кључне речи: полихлоровани бифенили, Aroclor1254, ELISA, млеко

Received: 7 December 2018

Received in revised form: 12 January 2019

Accepted: 25 January 2019 